\title{
Study on Innovation of Ecological Tourism Governance Mode in Indigenous Ethnic Minority Areas of Yunnan Province
}

\author{
Liu Huibai \\ Chuxiong Normal University, \\ Chuxiong, Yunnan,P.R.China, 67500 \\ Email: 472611181@qq.com
}

\author{
An Min \\ Chuxiong Normal University, \\ Chuxiong, Yunnan 67500
}

\author{
Kuang Ziming \\ Chuxiong Normal University, \\ Chuxiong, Yunnan 67500
}

\begin{abstract}
Yunnan boasts excellent traditional eco-culture of indigenous ethnic minorities, which is the root and soul for ecological tourism development. The ecological tourism governance mode in indigenous ethnic minority areas in Yunnan is a core knowledge system, which is abstracted from management practice experience and based on the fact that ecological culture ecotourism is a solution to the problem. It is a must to rebuild the way and operation logic for national authority to get involved in indigenous ethnic minority areas in Yunnan, and highlight on developing, fostering and expanding these areas' intrinsic social forces.
\end{abstract}

Keywords-Indigenous Ethnic Minority Areas of Yunnan Province; Ecological Culture; Ecological Tourism Governance Mode

The self-organization and social capitalist cultivating innovation of the social layer and the inherent strength growth are necessary elements to realize governance objectives and value orientation. Only when "positive energy is mutually delivered between the state and the society"1, the national governance system and capability modernization can take steadfast steps forward. The authors hold the opinion that innovation of ecological tourism Governance Mode in indigenous ethnic minority areas of Yunnan is an important growth point to promote local and even national Governance Modernization from the social level.

\section{I.THE CONCEPT OF ECOlOGICAL TOURISM GOVERnANCE MODE}

The mode is the rule discovered and abstracted from repeated events, and it is the conclusion and summarization of experience to solve problems. Ecological tourism Governance Mode means the core knowledge system in multicenter (multiple cooperation) treatment areas, which is derived from governance practice experience and based on the fact that

Fund program: Yunnan Province Philosophy and Social Science Planning Program: Study on Innovation of Ecological Tourism Governance Mode in Indigenous Ethnic Minority Areas of Yunnan (YB2013107).

National Social Sciences Fund Program: Study on Long-Term Mechansim for Maintaining Social Stability in Multi-Ethnic Border Areas of Southwest China (15bzz020)

1 Yang Guangbin: "China national Governance Modernization under World Political Viewpoint", “Administrative Tribune”, the $5^{\text {th }}$ issue of 2015 ecological culture ecotourism is a solution to the problem. According to the definition, it can be seen that:

Firstly, why ecological tourism Governance Mode is different and unique from other Governance Modes is because ecological tourism, which is a core base point. Different countries and areas have difference in existed systems, structures, traditions, ungovernability, etc., so there is none uniform mode for governance practice. Fundamentally the Governance Mode difference lies in completely different solutions to public problems, while ecological tourism Governance Mode is the governance system that ecological tourism is the core solution to solve problems in the community.

Secondly ecological tourism governance mode is derived from practice and sublimated from practice. The practice here refers to all practice to realize governance in ecological tourism and develop ecological tourism in governance. Governance and ecological tourism are two completely different discourse systems, but their "mutual dependence and cooperation, harmony and coexistence" value orientations and spirit concepts are especially fit and unity, so it is possible to have organic unity of governance and ecological tourism in practice. The governance mode based on the practice above is the ecological tourism governance mode. Ecological tourism governance mode is better than practice, and it refers to the knowledge system extracted and sublimed from practical experience, which is of reference and guidance to other areas, i.e. to be copies by others, which is diffusivity in linguistic language.

\section{INHERENT LOGIC FOR INNOVATION OF ECOLOGICAL \\ TOURISM GOVERNANCE MODE IN INDIGENOUS ETHNIC MinORITY AREAS OF YunNAN PROVINCE}

Ecological tourism Governance Mode is a mode conception based on special geography, history, culture and social conditions of indigenous ethnic minority areas, which decide that it is not only necessary but also possible and feasible to choose ecological tourism governance mode.

\section{A.Inherent Logic for Ecological Culture and Governance}

Yunnan is a province of many ethnic minorities, including 25 indigenous ethnic groups with a population over 5,000, such as Yi Minority, Bai Minority and Hani Minority. In the 
long survival and evolution history, indigenous ethnic minorities form their unique production and living ways, i.e. "ecological culture". This ecological culture is quite inherently consistent with governance.

Firstly ecosystem conservation and ecological civilization based on ecological culture are the important foundation, value orientation and fundamental objectives for governance, ecological harmony and sustainable environment development are the indispensible part of governance. ${ }^{2}$ Therefore, the traditional ecological culture that ethnic minorities stress ecological conservation agrees with the governance concepts inherently.

Secondly traditional customs that carry and display or contain ecological culture has the nature and function of public authority in certain scope, and they play the role of public power to some extent. Generally the existence of social forces except state power is the necessary condition and precondition for governance. As a result, traditional customs objectively provide the root and foundation to develop modern governance concepts and practice.

Lastly traditional customs (public authority) which contain ecological culture conceive "natural" cooperative partnership. Generally and principally traditional customs of ethnic minorities are compulsory in moral significance. Plus, due to the limitation of productive forces levels, awe to the nature, and dependency on the environment, it's easy for people to form a united, collaborative, compromising and tolerant cooperative partnership. Therefore, almost all ethnic minorities' traditional culture contains profound united, collaborative, neighborly, mutual aid, tolerant, and harmonious cultural spirit. ${ }^{3}$ This culture spirit caters for and coincides with cooperative relations (partnership), the spirit of modern governance.

\section{B.Ecological Tourism Governance Innovation: Management Based on Ecological Culture}

Ecological tourism demonstrates ecological cultural value and significance, and it is the best example to interpret and uphold contemporary ecological culture. It is "the sustainable tourism way that has environmental education functions, and is helpful for community economic development, cultural protection and ecological stability"; 4 and it is the practice for people to seek for life harmony and comfort. The concept of ecological tourism proves that it considers it as the precondition to respect local culture and ecosystem conservation planning and control; as the key point to return to the subjectivity of indigenous people, seek for the homogeny between human and the nature, and pursue community development autonomy; as the goal to realize benign interaction between people and harmony between the society

\footnotetext{
2 Refer to Ma Baobin: "Public Governance Theories and Practice", Social Science Academic Press, 2013 edition, page 14-17.

${ }^{3}$ Zheng Weichuan: "Uphold Excellent Traditional Culture of Ethnic Minorities, Build Socialism Spirit Civilization", “Advanced Ideology", the $5^{\text {th }}$ issue of 1997.

${ }^{4}$ Ye Wen, Xue Ximing: "Ecological Civilization: Eco-Culture and Ecotourism in Ethnic Community", China Social Sciences Publishing House, 2013 edition, Page 39.
}

and ecology. Hence it can be seen that ecological tourism and governance are inherently consistent.

As a result, in order to realize governance based on ecological culture, contemporary indigenous ethnic minorities in Yunnan are required to choose ecological tourism governance mode objectively; just based on the unique and splendid ecological culture of ethnic minorities, the governance and ecological tourism in ethnic minority areas are well mixed and consistent. As a result, it can be concluded that the innovation of ecological tourism governance mode in indigenous ethnic monitory areas of Yunnan is "to realize ecological tourism in governance and vice versa".

III. THE PRACTICAL FOUNDATION FOR THE INNOVATION OF

ECOLOGICAL TOURISM GOVERNANCE MODE IN INDIGENOUS ETHNIC MONITORY AREAS OF YUNNAN

Firstly flourishing development practice of ecological tourism in Yunnan nationality areas provides room and serves as the growing soil for ecological tourism Governance Mode innovation. Yunnan boasts good ecological environment, charming natural sights and gorgeous ethnic culture. Moreover, people are in harmony with their land. For example "terrace of Hani Ethnic Minority, Jade Dragon Snow Mountain of Lijiang, Dongba Culture of Naxi Nationality, Cangshan Mountains, Erhai Lake and Nanzhao Culture of Dali, tropical rainforests of Xishuangbanna and stilt style architecture of Dai Nationality all display the natural harmony between natural scenery and national culture". ${ }^{5}$ In the $21^{\text {st }}$ century, ecological tourism in pursuit of harmony between human and nature emerges and increasingly becomes the mainstream for $21^{\text {st }}$ century worldwide tourism industry development. Under this context and background, "Yunnan Province sees rapid ecological tourism development, the figure of ecological tourism tourists of customer markets is on the rise by $15 \%$ annually on average, the ecological tourism income increases by $19.7 \%$ annually on average" ${ }^{\circ}$, and the ecological tourism is more and more appealing at home and abroad.

Secondly the practical experience of Piyaway of Atayal Nationality in Fuxing Township, Taoyuan Township, Taiwan, China provides direct references and examples for innovation of ecological tourism Governance Mode in indigenous ethnic minority areas of Yunnan. Piyaway is located in the slope area, right bank and upstream of Dahan Stream, North Taiwan, and upward side at $36 \mathrm{~km}$ of Beiheng Road. Aborigines are all Atayal. The local Governance Mode is that under the stipulations of governmental laws and decrees, aborigines organize meetings, churches and women's meetings by depending on its traditional culture and ecological wisdom, jointly develop their ecological tourism, and get devoted to sustainable environment development. "In the modernization development course, the area doesn't open up too much due to commercial tourism and worldly capitalism so as to seek for the maximum profit, and get caught in crisis like losing

\footnotetext{
${ }^{5}$ Zhang Jie: "Reflection on Yunnan Ecological Tourism Development", "The Border Economy and Culture", the $10^{\text {th }}$ issue of 2009.

${ }^{6}$ Zhang Jie: "Reflection on Yunnan Ecological Tourism Development", "The Border Economy and Culture", the $10^{\text {th }}$ issue of 2009 .
} 
subjectivity, traditional social culture collapsing, natural ecological environment destroying... On the contrary, with the tribe innovative Governance Mode, they give their ancestral culture and ecological wisdom into full play, rebuild the collaboration among their native people, run the ecological tourism collectively, apply modern operation governance and online marketing techniques, and successfully set an example of ecological tourism " , the tribe ecological environment, ecological quality and resident income become better remarkably.

\section{Policy Advice AND OUTLOOK ON ECO-TOURISM GOVERNANCE INNOVATION IN YUNNAN INDIGENOUS ETHNICITIES INHABITANCES}

\section{A. Trial Adjustment in State-Society Relation}

For starters, in state and society relation, the state is subordinate yet society is decisive. The state is subject to and serves society. The gradual transfer of state power to society and nationals is the trend of social development.

For another, the primary stage of socialism requires a harmonious and complementary state-society relation. Social governance in current stage is not about weakening government, but empowering government, calling for a "strong government" to promulgate strategic rules, dominate affairs as well as provide service. Its more eager call is a "government in good administration" who will set up in theory and practice a complementary state-society relation featuring equity, collaboration, mutual check and mutual benefit. $^{9}$

Thirdly, a trial state-society relation adjustment can be put in practice in the current countryside governance in ethnicities inhabitances, specifically because: (1) the reform for a complementary state-society relation is not necessarily fitting with current system despite its compliance with the basic spirit of the Constitute, posing rather considerable difficulties and risks to the reform; (2) the traditional social force in indigenous ethnicities inhabitances is more powerful in its effect and function than that in other non-ethnicities areas; (3) ecotourism Governance Mode in Yunnan indigenous ethnicities inhabitances is in the general national interests as well as the essential interests of local residence; (4) the trial adjustment efforts is limited to small population and coverage.

\section{B.Mode and Operation Remaking in State Involvement in Yunnan Indigenous Ethnicities Inhabitances 1)Remaking of Party Organizational Function ${ }^{10}$}

\footnotetext{
${ }^{7}$ Liu Arong: Innovative Mode in Local Governance: Case Study on the Sustainable Development between a Taiwan Indigenous Inhabitance and the Environment, Essays on Local Governance in Ethnicities Inhabitances in the 2012 Annual Meeting of China Sociological Association, Page 246

${ }^{8}$ Its essential feature is the cooperative management in public life by government and citizens.

${ }^{9}$ Ma Baocheng: Governance at Countryside Level: System and Performance, Chinese Society Publishing House, 2010, Page 33

${ }^{10}$ Chen Xiaoli, Studies on Country Governance Entities and their Behavioral Relations at New Times, Chinese Society Science Publishing House, 2012 Page 283
}

In a diversified Governance Mode, local and glass-roots party organizations, especially from country level, shouldn't and are impossible to govern social public affairs specifically and directly. In terms of their functions they cannot automatically direct mandate as an omnipotent organization and unduly intervene among its governance subjects, nor are allowed to compete with other entities and organizations for power and interests. Their function is for general political leadership in oriental, overall and essential issues (such as national unification, political security and ethnic solidarity).

Such a function positioning requires party organizations (mainly CPC committees at township level and grass-roots level) to play their part as society integrator in the ecotourism Governance Mode innovation. Shouldering the duty to lead social value, integrate interests and regulate behaviors, they should, on the one hand, coordinate the relationship between villagers and governments from upper level and build a platform of information communication to express villagers' will and upper-level government's policies; on the other hand, they should cooperate with CPC country committees, religious groups and churches as partners, respect their relative independence and guide them with ease. By giving a full play to the vanguard role of CPC members, they are enabling diversified governance entities within or outside the party organization to trust, cooperate with, and interact with each other for the common goal of ecotourism development and the sustainability of economy and society.

\section{2)Functional Shift for Township-level Governments}

"At the last tier in China's five-tier government system, township-level governments' most fundamental and central function is not in economy and market regulation, but in public service" 11 . Catering to the demands in innovating ecotourism Governance Mode, township-level governments in Yunnan indigenous ethnicities inhabitances, on the one hand provides basic public service (in infrastructure, social stability, countryside charity and others) to locals, on the other hand create conditions as well as service to other governance entities for ecotourism development.

This speaks to the immediate liberation of township-level governments from a pressurized system. By making reference to foreign local self- governance regulations and central-local governments power division, on the one hand governments from central, provincial, county and township level can be divided in terms of their function, authority, duties, financial rights with reasonably assigned work between upper-lower level governments in three-tiered structure, thus forming a depressurization system; on the other hand, the amendment to autonomous regulations in self-governing regions, states, counties and townships serves as a wedge point, and the special system arrangement of regional ethnic autonomy could be a use in changing the pressurized system to avoid much pressure for grass-roots governments to bear.

\footnotetext{
${ }^{11}$ Li Ping, Functional Shift for Township-level Governments and the Development of Farmers' Specialized Cooperative Organizations in New Rural Building, Chinese Public Administration, the $5^{\text {th }}$ issue, 2008
} 
3)Highlight on Social Forces Development and Nurture in Ecotourism

The first is to change the status quo where local governments limit public organizations, a detriment not only to the development of those organizations, but public affairs management and public service supply. Therefore, Yunnan governments from all levels should shift their administration concept to grand enough trust and system space to public organizations to guarantee reasonable work assignment and effective cooperation between them and progress in public administration.

The second is to mobilize civil organizations and other social forces in ecotourism. The central government proposes a social governance structure of leadership from CPC committees, responsibility on governments, coordination by society and public engagement. It requires: in terms of governance means, comprehensive management by means of laws, regulations, policy, administration, values and others; in terms of Governance Mode, unified management forces in coordination, autonomy, self-discipline, discipline and mutual discipline through the modes of interests expression, democratic consultation, service providing, education and self regulation by society; and in terms of governance aim, maintenance of social order, solutions to social problems and uplift of social vigor. Strengthened social forces are the premise and foundation of social governance innovation. Therefore, for the sound development of ecotourism self organizations in the ethnicities inhabitances, it is a request to build system space, establish taxation and industrial policies, provide financial support in forms of planning and incentives and build platform to share information, promote capability and quality.

\section{REFERENCES}

[1] Ma Baobin: "Public Administration Theory and Practice", Social Science Academic Press, 2013 edition
[2] Ma Baocheng: Governance at Countryside Level: System and Performance, China Social Science Publishing House, 2010

[3] Chen Xiaoli, Studies on Country Governance Entities and their Behavioral Relations at New Times, Chinese Society Science Publishing House, 2012

[4] Zheng Weichuan: Carrying Forward Traditional Ethnic Culture, Nurturing Socialist Culture, Thinking, the 5th issue, 1997

[5] Yang Guangbin: the Modernization Of China's State Governance from The Perspective of Global Politics, Administrative Tribune, the 5th issue 2015

[6] Zhang Jie: "Reflection on Yunnan Ecological Tourism Development", "The Border Economy and Culture", the 10th issue of 2009.

[7] Liu Arong: Innovative Mode in Local Governance: Case Study on the Sustainable Development between a Taiwan Indigenous Inhabitance and the Environment, Essays on Local Management in Ethnicities Inhabitances in the 2012 Annual Meeting of China Sociological Association,

[8] Li Ping: Li Ping, Functional Shift for Township-level Governments and the Development of Farmers' Specialized Cooperative Organizations in New Rural Building, Chinese Public Administration, the 5th issue, 2008 